https://doi.org/10.18485/kud_kiaz.2019.ch18

Dilara Ismailova

Today multiculturalism is a state policy as well as

lifestyle in Azerbaijan

Ilham Aliyev

President of the Republic of Azerbaijan

\title{
TEACHING ENGLISH IN A MULTICULTURAL CONTEXT AT THE AZERBAIJANI UNIVERSITY OF LANGUAGES
}

\section{SUMMARY}

Azerbaijan is a country of rich cultural and spiritual heritage and traditions of tolerance. Today, this truth is recognized on the international arena.Multicultural and tolerant values have universal character.The atmosphere of tolerance is always at the highest level in Azerbaijan. The multiculturalism which has turned into a state policy appears as an invariable lifestyle in modern Azerbaijani society.

Key words: multiculturalism, tolerant, integration, competence.

Today, Azerbaijan is a full member of such authoritative organizations as the UN, OSCE, the Council of Europe, the Organization of Islamic Cooperation, and GUAM. Azerbaijan successfully continues process of integration into Europe within the Eastern Partnership project implemented by the European Union.

Azerbaijani multiculturalism has got international recognition and is subject of study in many organizations and universities around the world. 


\section{Education}

The independent Azerbaijani state and its founder HeydarAliyev always showed attention and care for languages, culture, customs and traditions of the ethnic minorities living in the country.

"Azerbaijani Multiculturalism" is included in curricula of 13 prestigious higher education institutions of the world countries and 28 higher education institutions of Azerbaijan.

On 22 September Baku International Centre of Multiculturalism held a presentation of a university textbook "Azerbaijani Multiculturalism".

The textbook "Azerbaijani Multiculturalism" to be taught at universities has been developed under the scientific editorship of Academician Kamal Abdulla, the Chair of the Board of Trustees of Baku International Centre of Multiculturalism, Rector of Azerbaijan University of Languages and Professor EtibarNajafov, the Chief Adviser of the Department of Interethnic Relations, Multiculturalism and Religious Affairs of the Administration of the President of the Republic of Azerbaijan.

Integration of the education system of Azerbaijan in the international, including in the European educational space is possible on condition of close cooperation with the international organizations. With respect thereto, one of the main activities of the Ministry of Education consists in strengthening of communications and mutual cooperation with the international organizations. A specific place among such communications is held by development of cooperation with the Council of Europe, participation in the international and regional education programs realized by this organization.

Multicultural education is an approach to education that aims to include all students, promote learning of other cultures, and teach healthy social skills in a multicultural setting. "It is the present and future of education," according to Allison, B.N. (2007, p.99)., who runs a business offering online 
courses to students worldwide. "Multicultural classrooms are a melting pot of learning," the author says. "Rather than a passive, one-way flow of learning from teacher to student, there is a brainstorming of ideas, stories, and experiences that enrich the educational experience in ways that are impossible in monocultural classes.

The English language classroom provides an obvious multicultural context for learning, and teachers need to help students understand and appreciate the differences and similarities among the various ethnic, religious and cultural groups. This study aims to examine teachers' understanding of and attitudes towards multiculturalism, and in so doing, find out what are the language teaching strategies used in promoting and enhancing successful multicultural interactions. Teachers should be able to seize this opportunity to foster tolerance and understanding in classrooms of diverse cultural backgrounds.

The main aim of foreign language education in Azerbaijan is developing intercultural competence that overlaps foreign language communicative competence as one of its integral parts. We consider foreign language communicative competence as a prerequisite for intercultural competence and that intercultural competence embraces mostly the ontological aspect of personality molding whereas communicative competence covers the language and speech skills of an individual. In a most general way intercultural competence can be defined as the ability to realize oneself in a cultural dialogue. This main idea can be differently interpreted.

The teaching methodology is based on some different approaches for any language learning context. The first approach is the communicative approach of language teaching; where explanation of different ways and strategies can be used to give the students a major role in their own learning. This is based on using the target language and implementing interactive activities that engage the students in meaningful ways. Communicative language teaching (CLT), or the communicative approach, is an approach to language teaching that em- 
phasizes interaction as both the means and the ultimate goal of study.

Language learners in environments utilizing CLT techniques, learn and practice the target language through the interaction with one another and the instructor, the study of «authentic texts» (those written in the target language for purposes other than language learning), and through the use of the language both in class and outside of class.

Learners converse about personal experiences with partners, and instructors teach topics outside of the realm of traditional grammar, in order to promote language skills in all types of situations. This method also claims to encourage learners to incorporate their personal experiences into their language learning environment, and to focus on the learning experience in addition to the learning of the target language. Nunan, $\mathrm{Da}$ vid (1991 p.25). According to CLT, the goal of language education is the ability to communicate in the target language. J., (Savignon, Sandra,1997,p.45).

The second approach is teaching culture, where how and what to teach students in order to raise their cultural awareness of the second language. English as an international language has also started to develop a close affinity with research in the area of intercultural communication. English is widely used for intercultural communication at the global level today. It is becoming increasingly recognized that «intercultural competence» needs to be viewed as a core element of «proficiency» in English when it is used for international communication. It is true that Miller(1997, pp. 88-90) asserts that despite the need for some culture, users of English as an international language do not need to internalize the cultural norms of the original native-English speaking countries in order to effectively utilize the language. Since English as an international language does not necessarily «belong» to any country but what teachers do need to recognize is the need to broaden their students' horizon beyond the purely linguistic aspects by placing greater weight on the cultural background of the 
target language (TL) countries, and Trying to raise some kind of intercultural awareness which, in time, bring about Intercultural Communicative Competence. According Alptekin, C. (2002, pp.57-62) towards intercultural communicative competence. this comprehensive competence integrates the cognitive (knowledge of languages and cultures, as in traditional, the pragmatic (the competence to perform speech acts) and the attitudinal domains (open-mindedness and tolerance, as in political education) within FL learning. Therefore, teachers need to develop some sort of intercultural dimension in the classroom.

Importance of Cultural Awareness for Intercultural Communication in the Teaching of English as an International Language.

Intercultural awareness in language learning is often talked about as though it were a 'fifth skill' - the ability to be aware of cultural relativity following reading, writing, listening and speaking. Language itself is defined by a culture. We cannot be competent in the language if we do not also understand the culture that has shaped and informed it. We cannot learn a second language if we do not have an awareness of that culture, and how that culture relates to our own first language/ first culture. It is not only therefore essential to have cultural awareness, but also intercultural awareness. Then, it is necessary to review these key elements and their relevance to accomplish the purpose of the second approach:Intercultural communication: common, necessary part of people»s personal and professional lives;

Intercultural competence: ability to become effective and appropriate in interacting, the sensitivity to cultural diversity;

- Cultural awareness: an important role to overcome difficulties to ensure smooth communication with people from different backgrounds

- Intercultural communication competence: ability to effectively and appropriately execute communication behaviors to elicit a desired response in a specific environment. 
And the third approach is the use of technology inside the language classroom in a way to find new venues where students can have multiple language exposures. The application of classroom tools which involve the use of new technologies is gaining more and more supporters and is practiced frequently, not only in private schools (which are usually better equipped and provided with high-quality teaching materials), but also it made its way to the public schools, where foreign language lessons are more and more often supported by digital materials.

The process of teaching is enhanced with interactive technologies, among which are reflexive, student-centered methods, such as discussions, debates, case-study, role-playing, project activities and other ways to develop critical thinking and learning autonomy of the students.

The usage of tools described above depends on availability of technological devices. Starting from the basics, a personal computer with a possibility to display the image for all the students to see, so with a projector, an interactive board or a TV set. Internet connection is not always necessary, although, it makes lessons easier to prepare and quicker in a matter of interaction. A teacher equipped with such a set can benefit from digital resources and tools efficiently. Students, using modern technological devices individually, can revise and experience authentic materials provided by a teacher either during classes, or at home. Being able not only to watch but to participate actively, makes students more involved and satisfied with the results obtained. That is why, both students and teachers should have an access to the variety of multimedia through different technology devices.

\section{Teaching English to Azerbaijani students in Multicultural Classrooms}

The English language classroom provides an obvious multicultural context for learning, and teachers need to help 
students understand and appreciate the differences and similarities among the various ethnic, religious and cultural groups. This study aims to examine teacherse understanding of and attitudes towards multiculturalism, and in so doing, find out what are the language teaching strategies used in promoting and enhancing successful multicultural interactions. Teachers should be able to seize this opportunity to foster tolerance and understanding in classrooms of diverse cultural backgrounds.

The classroom is a critical social arena where individual lives are shaped and influenced through attitudes and values, which are embedded in both the content and the process of learning. Positive values, for example, an acceptance and conceptual understanding of difference, are important to success (Byram, M. (1997, p.63). Teaching and assessing intercultural communicative competence multilingual matters.

Modeling awareness of our own culture and its influence on how we approach the lesson allows students to explore their own culture. Students can then begin to question how their own values influence how they interact with and think about individuals who differ from themselves. We should also inform students that they do not have to agree with us or accept our values. Culture affects the way we teach and therefore we really cannot engage in bias-free teaching. We constantly convey our values to students by the way we talk, or do not talk about individuals, about people with different cultural backgrounds. If we want our students to understand culture and its effects on others then multiculturalism need to be injected or infused in the curriculum. Students live in a diverse world and teachers need to provide the relevant opportunities to apply this intercultural understanding in their daily lives. It is important to emphasize, that teachers must remain mindful of their values and seek to identify and address ways in which their biasness interfere with their ability to engage in culturally competent teaching. Language is a vital means of transmitting culture and a common source of confusion, even among members of the same culture .Every language is part 
of a culture, and it serves and reflects cultural needs. Even so there are areas in the world where societies share a very similar cultural orientation and yet speak languages that are not only mutually unintelligible but completely unrelated and structurally different. This is especially true when we have a class of students learning, speaking English, all from varied cultural background. The importance of the language to be taught to all students.

Due to the lack of understanding of ethnic, racial, social, and linguistic diversity of students, teachers can engage themselves consciously or unconsciously in practices that may not be suitable in the classroom. Due to the failure on the part of teachers to understand, accept, and appreciate who these students are, students may feel that the learning environment is alien and hostile toward them. This situation causes stress, anxiety, and a feeling of a lack of support among students, which can affect students ${ }^{\text {ee }}$ daily academic performance.

While teachers agree that knowledge of multiculturalism is important, there were a few who did not show any concrete behaviour in promoting it in the class. An experienced teacher of seven years felt that it would certainly be helpful in the adult language class based on the experience she had. She admitted the awkwardness when she assumed that the students ${ }^{\text {ee }}$ knowledge background were of the same level, being in the same level of English proficiency class. Much to her surprise she was assuming too much when she thought the students did not have problems doing the task assigned. She was not aware that where the students were from had no access or exposure to the popular branded items she wanted identified. The inexperienced teachers said reminders on existence of cultural differences, listening to their opinions, voices, avoid prejudices, give tasks on essays of studentse different cultures, food, and generally choose and design topics and techniques that could bring forth discussions and different points of view.

Teaching effectively in a multicultural classroom requires culturally sensitive strategies and content to provide equal 
opportunities for academic success and individual growth of all students. The most effective teachers have learned to understand the cultures of students and their students trust them Byram, M. (1997, p.61). Teaching and assessing intercultural communicative competence multilingual matters.

Teachers need to develop an awareness of their own cultural perspectives, beliefs and behaviors and to be aware that their own cultural perspective is not the universal perspective and the only right one. Pre-service teachers need to acquire multicultural competence, the ability to be functional in cross-cultural settings. The teaching strategies seen by the teachers as could be effective in dealing with the students came about because of some of the difficulties experienced during their teaching practicum.

Although multiculturalism is a common issue in the world, it is not much stressed in teacher training programmes. Teachers can become culturally sensitive and knowledgeable about second language acquisition, provide culturally responsive instruction and content that reflects central aspects of a culture and use highly motivating instructional materials. It is apparent that the participants find it agreeable for teachers to be trained. Suggestions and recommendations from the interviewees wanted some kind of short courses. There is need to know what goes on in their minds give students and what they feel about the differences in culture especially when they interact amongst themselves as learning does not only take place in the classroom but outside, or informally as well. Not well-equipped with the knowledge and the teaching experience most of them they felt that a proper training session on multiculturalism should be given. Specific topics like intercultural communications should be introduced so that teachers as well as students could be more psychologically prepared in dealing with multicultural facets and issues. 


\section{Conclusions}

This paper is based on a small study focusing on the teaching of English at the university of languages in Azerbaijan. Studying teachers perceptions concerning their preparation to work with culturally diverse students assist the teacher programs to prepare teachers to work more effectively with culturally diverse students. Teachers need to involve themselves in critical reflection and learn to appreciate cultural diversity in the university. It is thus imperative for universities to provide opportunities for teachers to think about and discuss cultural diversity. Teachers today are faced with the many challenges of educating students who are from very varied cultural backgrounds. The purpose of this study is thus to examine what the teachers ${ }^{\text {ee }}$ understanding of multiculturalism is and what were some of the teaching strategies adopted in promoting multiculturalism. Teaching English in a Multicultural context is significant in three approaches: the first approach is the communicative approach of language teaching; the second approach is teaching culture, where how and what to teach students in order to raise their cultural awareness of the second language; and the third approach is the use of technology inside the language classroom in a way to find new venues where students can have multiple language exposures.

The English language classroom provides an obvious multicultural context for learning, and teachers need to help students understand and appreciate the differences and similarities among the various ethnic, religious and cultural groups.

\section{References:}

Allison, B.N. \& Rehm, M.L. (2007). Teaching strategies for diverse learners in FCS classes.Journal of family and consumer Sciences. 99,

Alptekin, C. (2002). Towards intercultural communicative competence. ELT Journal, 56(1):57-64.

Byram, M. (1997). Teaching and assessing intercultural communicative competence multilingual matters. 
Clevedon: Multilingual Matters.

Miller, Howard M. «Beyond 'Multicultural Moments' (Middle Gorund).» English Journal 86 (1997): 88-90.

Nunan, David (1991-01-01). "Communicative Tasks and the Language Curriculum». TESOL Quarterly. 25 (2): 279295. doi: $10.2307 / 3587464$

J., Savignon, Sandra (1997-01-01). Communicative competence : theory and classroom practice: texts and contexts in second language learning. McGraw-Hill. ISBN 9780070837362. OCLC 476481905.

Clevedon: Multilingual Matters.

Chao, T. (2011). The hidden curriculum of cultural content in internationally published ELT textbooks: A

closer book at new American inside out. The Journal of Asia TEFL, 8(2): 189-210

\section{PEЗЮME}

Эта статья основана на практическом исследовании, посвященном преподаванию английского языка в университете языков в Азербайджане. Преподавание английского языка в мультикультурном классе в Азербайджанском университете языков имеет три основных подхода: первый - коммуникативный подход к обучению языку; второй путь - преподавание культуры, где как и чему учить студентов, чтобы повысить их культурную осведомленность о втором языке; и третий путь - использование технологий в языковой аудитории, чтобы найти новые места, где студенты могут иметь несколько языковых навыков.

Первый способ - коммуникативный подход к обучению языку; где объяснение различных способов и стратегий может использоваться, чтобы дать студентам главную роль в их собственном обучении. Это основано на использовании целевого языка и реализации интерактивных действий, которые вовлекают студентов осмысленно.

Второй путь - это преподавание культуры, где как и чему учить студентов, чтобы повысить их культурную осведомленность о втором языке. Значение культурной осведомленности для межкультурной коммуникации в преподавании английского языка как международного. Межкультурная компетентность: способность становиться эффективными и адекватными во взаимодействии, чувствительность к культурному разнообразию.И третий путь - это 
использование технологий в языковой аудитории. Студенты и преподаватели должны иметь доступ к разнообразным мультимедиа с помощью различных технологических устройств.

Ключевые слова: мультикультурализм, толерантность, интеграция, компетентность. 